РОЗДІЛ ІІ. ПРОБЛЕМИ ПОРІВНЯЛЬНОЇ ПЕДАГОГІКИ Удк 378.015.3:001.895:378.094:61(73) «19»

\author{
Алла Куліченко \\ Запорізький державний медичний університет \\ ORCID ID 0000-0003-1469-3816 \\ DOI 10.24139/2312-5993/2020.03-04/171-181
}

\title{
ОГЛЯД ІННОВАЦІЙНОЇ ДІЯЛЬНОСТІ АМЕРИКАНСЬКИХ МЕДИЧНИХ КОЛЕДЖІВ УПРОДОВЖ 1934-1939 РР. У ПРАЦЯХ Г. ВАЙСКОТТЕНА
}

Статтю присвячено аналізу праць Г. Вайскоттена, зокрема «Тенденції в медичній практиці» (1937), «Медична освіта у Сполучених Штатах Америки 19341939 рр.: підготовано для Ради з питань медичної освіти та лікарень Американської медичної асоціації (1940) та «Тенденції в медичній практиці: аналіз розподілу й характеристик випускників медичних коледжів 1915-1950 рр.» (1960), які висвітлюють інноваційну діяльність американських медичних коледжів у 1934-1939 рр. 3'ясовано, що Велика депресія негативно вплинула на розвиток медичної освіти США. Проте, установлено, що під час економічної кризи у США Г. Вайскоттен провів а) опитування випускників 1930 р. та 1935 р. щодо кар'єрних успіхів; б) перевірку медичних коледжів США та Канади.

Ключові слова: американська медична освіта, Велика депресія, медичні коледжі, опитування випускників, інспектування, Г. Вайскоттен, «Доповідь» Вайскоттена, інноваційна діяльність, медичні дослідження.

Постановка проблеми. Від початку існування людства прослідковується тенденція бінарних опозицій «занепад - відродження» / «криза - розвиток» у всіх сферах життя. На зміну старому приходить нове, досконаліше за попереднє - нові можливості, погляди, концепції, технології тощо. Для американського народу різка зміна способу життя відбулася в середині осені 1929 р. під назвою «Велика депресія». Р. Марго слушно зауважує, що «Велика депресія - для економіки, як великий вибух - для фізики» (Margo, 1993). А. Мартинов зазначає, що «криза 1930-х рр. розпочалася відразу після доби процвітання, яке настало для США внаслідок перемоги країн Антанти в Першій світовій війні» (Мартинов, 2011).

Дослідник додає, що досі «в історичній літературі триває дискусія навколо питання, коли саме завершилася ця криза. Частина істориків уважає, що мова має йти про середину 1930-х рр., коли визначилася тенденція подолання кризи за допомогою різних інноваційних (курсив наш. - А.К.), як на той час, соціальних і політичних технологій. Причому вони були діаметральними за своїми характеристиками: від методів державного регулювання ринкової економіки, запропонованих президентом США Ф.Рузвельтом, і до жорстких авторитарних заходів нацистського та різного ґатунку фашистських режимів» (Мартинов, 2011).

Б. Штайншауер указує на те, що «30-ті роки були важкими для американської медицини. Мало хто міг дозволити собі медичну допомогу під 
час Великої депресії, і розрив між гомеопатичною та науковою медициною зростав після доповіді про медичні школи, яку замовив Фонд Карнегі 3 поліпшення викладання. Американська медична асоціація закрила більшість шкіл, які викладали гомеопатію, пропагуючи рослинні засоби й комплексне лікування. Більшість наукових медичних шкіл, що відповідали суворим вимогам, були у складі престижних університетів» (Steinshouer, n.d).

На думку Р. Вілбура, соціальні та економічні заворушення, спричинені кризою в усьому світі, загальмували значну частину прогресу, що відбувався в медичній освіті Америці наприкінці XIX ст. (Wilbur, 1940) й початку XX ст.

3 метою повторної перевірки 89 медичних шкіл, що продовжили функціонувати після «Доповіді» Флекснера та готували спеціалістів у перші п'ять років Великої депресії, Американська медична асоціація ухвалила рішення про залучення до складу Ради з питань медичної освіти та лікарень Американської медичної асоціації Германа Гейтза Вайскоттена (1884-1972). Його завданням була ретельна інспекція тогочасних 79 американських і 10 канадських шкіл упродовж 1934-1939рр. $з$ подальшою публікацією отриманих результатів.

Аналіз актуальних досліджень. У розвідці увагу сфокусовано на таких працях Г. Вайскоттена: «Тенденції в медичній практиці» (1937), «Медична освіта у Сполучених Штатах Америки 1934-1939рр., підготована для Ради з питань медичної освіти та лікарень Американської медичної асоціації» (1940), відомої як «Доповідь» Вайскоттена, та «Тенденції в медичній практиці: аналіз розподілу й характеристик випускників медичного коледжу, 1915-1950» (1960).

Доробки Г. Вайскоттена згадують зарубіжні дослідники, зокрема Дж. Вайс, П. Войчеч, С. Грейсен, В. Кешткар, В. Молл, Дж. Монаган, Р. Разаее, Дж. Шафер та ін. Крім того, до результатів перевірки Г. Вайскоттена, зафіксовані в «Доповіді», зверталися у 1955 р. об'єднана державна урядова комісія; у 1985 р. Комітет з питань харчування в медичній освіті, Рада з питань харчування, Національна наукова рада США та ін.

Варто зазначити, що у вітчизняному науковому просторі увагу на окресленому питанні не було зосереджено. Однак, інтерпретацію певних моментів «Доповіді» Вайскоттена, що стосуються інноваційної діяльності американських медичних коледжів у другій половині 1930-х рр., наведено у праці «Інноваційна діяльність у медичній освіті США (10-40 рр. XX ст.)» (Куліченко, 2020) авторки цього дослідження.

Метою статті $€$ аналіз праць Г. Вайскоттена 1937, 1940 та 1960 рр. 3 виокремленням інноваційної діяльності в американській медичній освіті 1934- 1939 рр.

Для досягнення мети дослідження було використано такі методи: бібліографічний - дозволив виявити науково-педагогічні джерела різних 
років із зазначеної проблеми; контент-аналіз, узагальнення, систематизація, що забезпечили виокремлення з праць Г. Вайскоттена певних аспектів інноваційної діяльності американських медичних коледжів у 1934-1939 рр. та подання їх цілісного огляду.

Виклад основного матеріалу. Перед тим, як перейти до розгляду «Доповіді» Вайскоттена з приводу огляду інноваційної діяльності американських медичних коледжів у 1934-1939рр., зупинимося на одній із ключових діяльностей Г. Вайскоттена в зазначений період, а саме опитуванні випускників, які отримали медичних фах у США та Канаді. Пов'язуємо цей момент із інноваційною діяльністю медичних коледжів університетів США 3 підготовки кадрів та управління людськими ресурсами. Оскільки результати подібних опитувань дають змогу закладам вищої освіти зосередитися не тільки на якіснішій підготовці майбутніх фахівців з тієї чи іншої спеціальності як у теоретичному, так і практичному аспектах, а й залучити потенційних вступників із віддалених регіонів країни.

За пропозицією Ф. Запффе, секретаря Асоціації американських медичних коледжів, у різні роки першої половини XX ст. Г. Вайскоттен проводив валідне дослідження-опитування 34174 випускників 1915 - 1950 рр. $з$ метою з'ясування їх кар'єрних досягнень та напрямів медичної практики. Значну увагу було зосереджено на випускниках періоду Великої депресії. Так, випускників 1930 р. із США та Канади було опитано через шість років після закінчення медичних коледжів (у 1936 р. - А.К.), випускників 1935 р. - через 15 років (у 1950 р. - А.К.) (Weiskotten, 1937; Weiskotten et al., 1960), у зв'язку з поступовим виходом Північної Америки з масштабної економічної кризи та її участю у Другій світовій війні.

Для нашого дослідження важливими $€$ випускники-респонденти 1930 р., оскільки отримання ступенів припало на початок світової економічної кризи, а діяльність - на їі розпал. Кожному випускникові було надіслано опитувальник (див. рис. 1), форма якого змінювалася впродовж наступних років. У свою чергу, випускники мали повернути поштою або особисто, якщо була така нагода, заповнені опитувальники Г. Вайскоттену (Weiskotten, 1937; Weiskotten et al., 1960).

За статистикою, випускникам 1930 р. 63 медичних коледжів США та 9 закладів медичної освіти Канади було надіслано 4958 опитувальників, а повернуто - 3710, що склало 74,8 \%. Результати опитування свідчили, що більшість випускників була невдоволена їх тогочасною професійною діяльністю. Коментарі респондентів свідчили про бажання а) кардинально змінити вектор медичної діяльності; б) отримати інші або вужчі спеціалізації, ніж ті, з яких практикували; в) пройти резидентуру або знайти можливість для післядипломного навчання 3 обраної спеціалізації; г) виконувати наукові дослідження. Проте, незважаючи на вищезазначене, 
випускники 1930 р. мали щирі наміри служити народу, попри скрутне становище в країні (Weiskotten,1937).

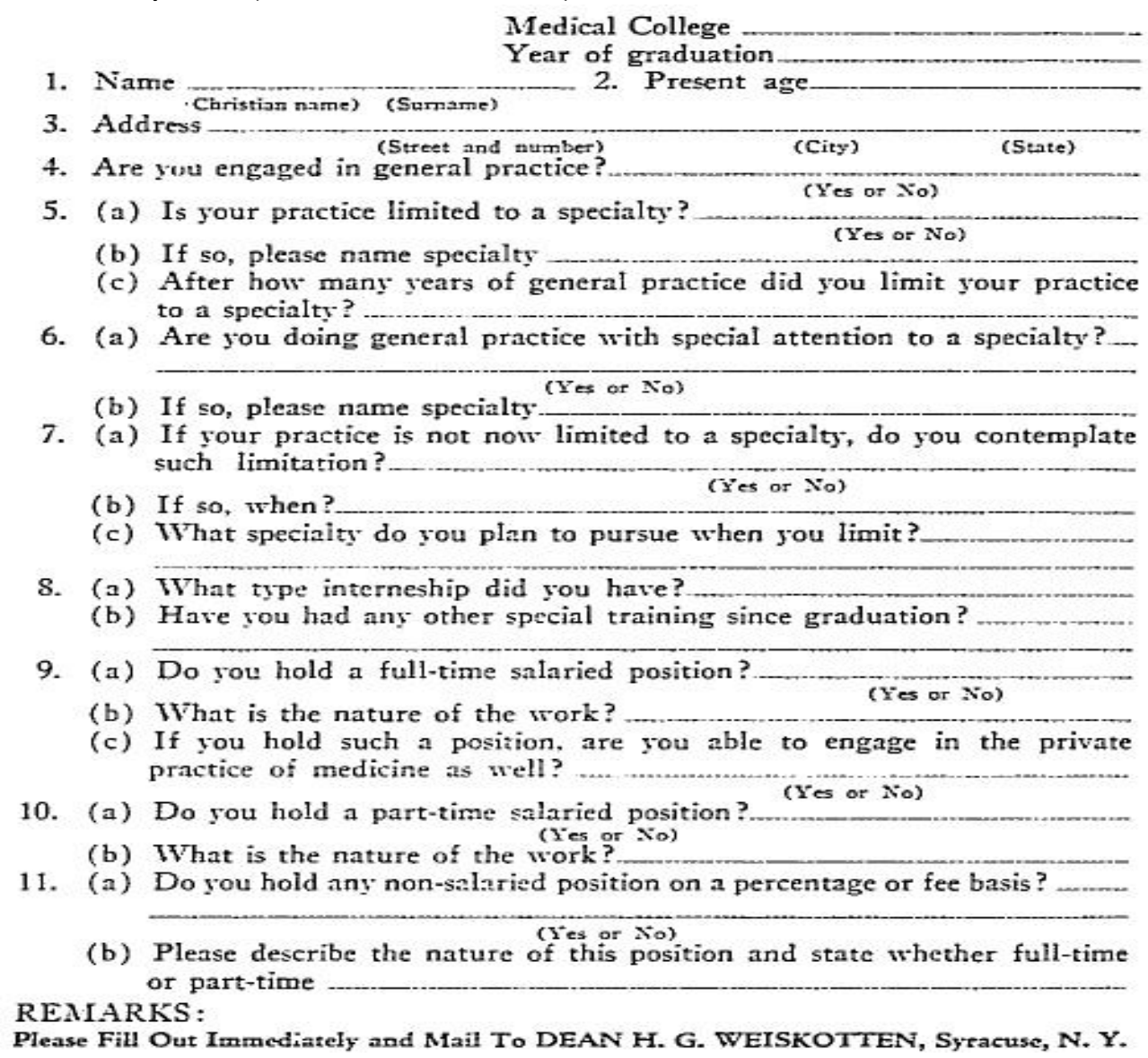

Рис. 1. Зразок опитувальника для випускників медичних коледжів США та Канади 1930 р. Джерело: (Weiskotten,1937)

Наведемо фрагмент відгуку, що належить випускникові одного 3 американських медичних коледжів 1930 р.: «Я активно працюю хірургом. Я перебуваю на посадах без платні. П’ятдесят відсотків моєї праці - ие благодійність. Я не очікую на платню, бо лікарня в моєму місті занадто зубожіла через політику країни. Проте я роблю все можливе, щоб урятувати хворих» (цит за: Weiskotten, 1937).

Г. Вайскоттен зауважував: «Жорсткіші умови вступу до медичних коледжів вочевидь не вплинули на загальний вік (24 роки - А.К.) студентів на момент випуску (1930р. - А.К.). Значний відсоток випускників канадських медичних коледжів практикують у США. Проте, відсоток тих, хто зостався працювати в США становить 24, що на $15 \%$ менше, порівняно з випускниками 1925 р. На територіальний розподіл випускників у США, скоріше впливає стан економіки, аніж населення» (Weiskotten,1937).

У 1934 році американська Рада з медичної освіти та лікарень ініціювала проведення нового інспектування всіх медичних коледжів 3 урахуванням змін у медичній освіті та проблем, що виникли під час останнього масштабного огляду в 1919-1922рр. Для якісного проведення 
комплексної перевірки Рада з медичної освіти та лікарень, ураховуючи численні напрацювання та розвідки з медичних освітніх питань, додала Г. Вайскоттена до ії складу та просила взяти участь як Асоціацію американських медичних коледжів, так і Федерацію державних медичних рад. Загалом, більшість перевірок та звітів виконував Г. Вайскоттен упродовж 1934-1939 рр. (Academic quality and..., 2017).

Станом на 1935 р. було перевірено 45 медичних коледжів і надано на розгляд попередні результати: необхідність перегляду освітніх стандартів, особливо стосовно поширеної практики деяких коледжів приймати велику кількість студентів, деякі з яких були некваліфікованим для продовження медичних досліджень (Academic quality and..., 2017).

Результатом тривалої перевірки медичних шкіл стала в 1940 р. розвідка Г. Вайскотена «Медична освіта у Сполучених Штатах Америки 1934-1939 рр.: підготовано для Ради з питань медичної освіти та лікарень Американської медичної асоціації» у співавторстві 3 А. Швіталлою, деканом медичного коледжу Університету Святого Луїса, В. Каттером, секретарем Ради з питань медичної освіти та лікарень Американської медичної асоціації, та Д. Андерсоном, доктором медицини.

У вступі до «Доповіді»Г. Вайскоттен зі співавторами зазначають, що «під час світової війни (першої - А.К.) було мало можливостей для розвитку інноваційної діяльності в медичній освіті, але за наступні півтора десятиліття деякі коледжі змогли досягти значних успіхів. <.> Цей розвиток, окрім фінансового аспекту, стосувався значною мірою викладання клінічних дисциплін та необхідних клінічних приміщень. Також спостерігалося постійне збільшення кількості студентів, які попередньо здобули освіту в гуманітарних коледжах та вступали на медичну спеціальність» (Weiskotten, 1940).

П. Войчеч вважає, що у 1940 р. «Доповідь» Вайскоттена продемонструвала невдоволення доклінічною освітою», оскільки проголошене в «Доповіді» Флекснера «наукове підґрунтя медицини» для навчального плану часто призводило до розділу доклінічних та клінічних дисциплін (Wojciech, 2009). Р. Разаее та В.Кешткар додають, що «Доповідь» Вайскоттена стала своєрідним маніфестом з цього приводу (Rezaee \& Keshtkar, 2013).

Що стосується інноваційної діяльності загалом у медичній освіті в 1934-1939 рр., констатуємо, що організація комплексної перевірки тогочасних медичних коледжів США та Канади $є$ яскравим прикладом управлінських інновацій.

«Конфіденційна доповідь Ради з питань медичної освіти та лікарень Американської медичної асоціації для медичних коледжів США та Канади», яку наведено в додатку А «Доповіді» Вайскоттена (Weiskotten, 1940), є доказом принципово нового підходу до тогочасних перевірок 
закладів медичної освіти. Цей документ складається з двох частин. Першу частину, яка є обґрунтуванням перевірки медичних коледжів, присвячено загальним принципам, меті перевірки, плану звіту, джерелам інформації, методам опрацювання інформації, структурі графічних зображень, що містять опрацьовану інформацію (pattern map). У другій частині подано детальний опис загальних критеріїв (структура, керівництво, бібліотека, факультети, освітня програма, клінічні заклади або приміщення, фінансування) та критеріїв, що стосуються доклінічних й клінічних кафедр.

Загалом, у документі йшлося про:

- шість доклінічних кафедр, а саме про кафедру анатомії; біохімії; фізіології; фармакології; бактеріології; патології;

- чотири клінічні кафедри - медицини; хірургії; гінекології; педіатрії (Weiskotten, 1940).

На рис. 2 наведено оцінку двох протилежних медичних коледжів за частиною II. «Конфіденційної доповіді Ради з питань медичної освіти та лікарень Американської медичної асоціації для медичних коледжів США та Канади», подану Г. Вайскоттеном у 1940 р.

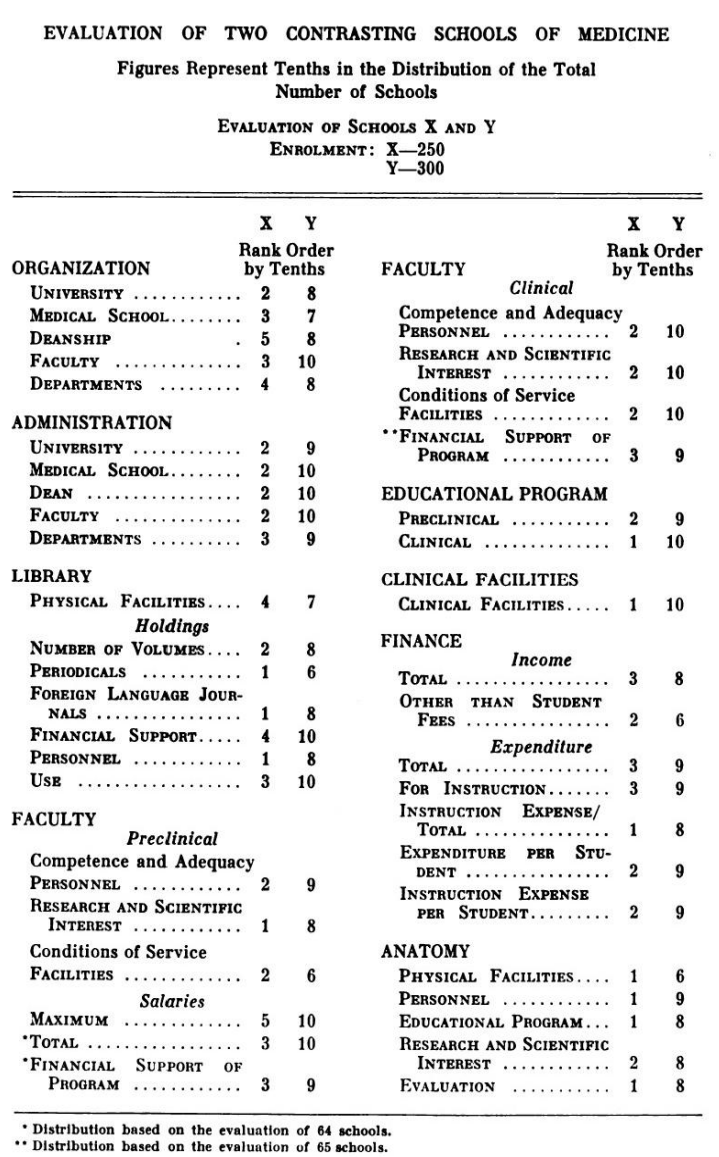

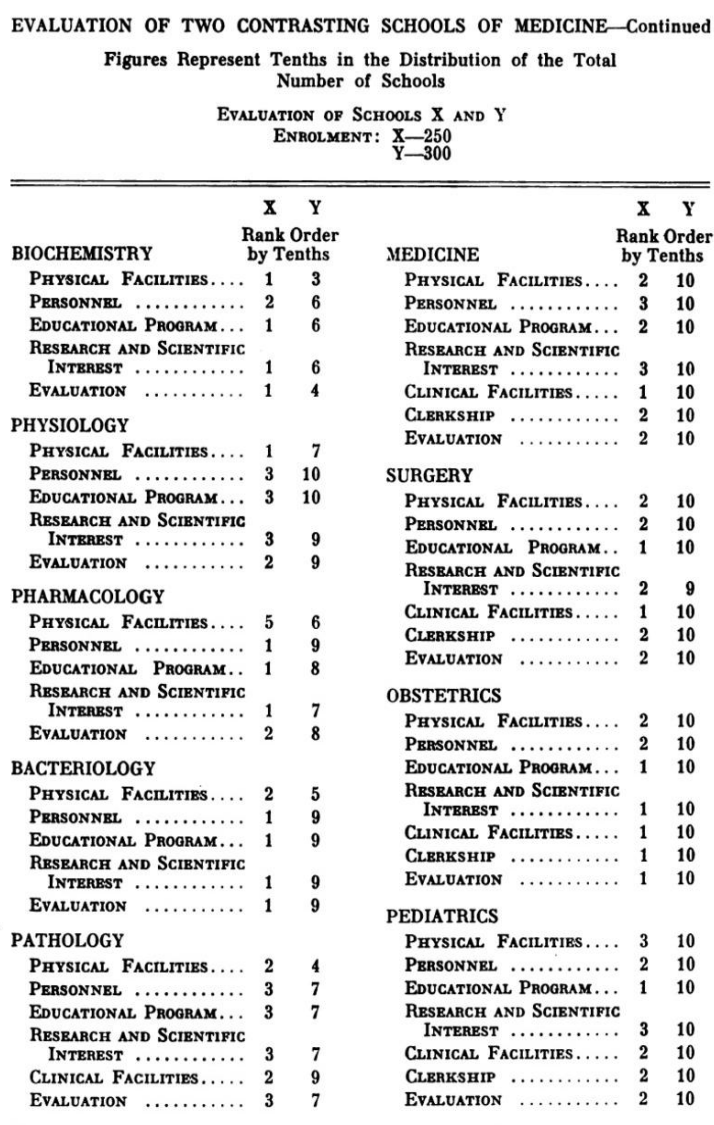

Рис. 2. Частина II. «Конфіденційної доповіді Ради з питань медичної освіти та лікарень Американської медичної асоціації для медичних коледжів США та Канади» на прикладі двох протилежно оцінених медичних коледжів. Джерело: (Weiskotten, 1940)

Г. Вайскоттен указував на відсутність єдності у функціонуванні як державних, так і приватних університетів, у складі яких були медичні 
коледжі (Weiskotten, 1940). Проте, вважаємо, що наведений у «Доповіді» аналіз організації освітнього процесу кожного медичного коледжу, його позитивний досвід також був проявом інноваційної діяльності.

Цікавим прикладом організаційної інноваційної діяльності $\epsilon$ призначення декана медичного коледжу. Традиційно, кандидатуру декана, освітяна-медика, обговорювала та призначала Рада попечителів закладу освіти. Однак, існували й інші варіації призначення:

- контролююча рада призначала декана;

- першим кроком до призначення було подання президентом університету кандидатур(и) на розгляд Радою попечителів;

- спеціальна об'єднана комісія Ради попечителів та професорськовикладацький склад медичного коледжу обирали й призначали декана;

- професорсько-викладацький склад медичного коледжу рекомендував Раді попечителів призначити певного кандидата;

- декана обирала щорічно керівна рада медичного коледжу шляхом таємного голосування, результати надавала адміністративній канцелярії університету, представник якої інформував контролюючу раду (Weiskotten,1940).

Однією з інновацій були коледжі соціального обслуговування (або соціальної роботи) у тринадцяти університетах. Важливим було те, що між ними та медичними коледжами, що підпорядковувалися цим університетам, існували освітні взаємозв'язки. Крім того, один університет відкрив коледж

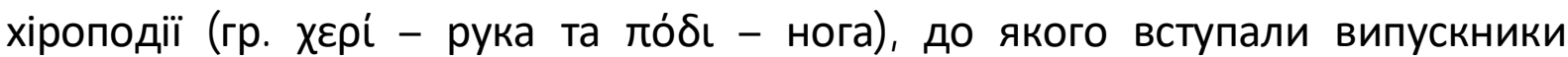
середньої школи, які опановували трирічну навчальну програму та ділили деяке обладнання зі студентами-медиками. у двох університетах функціонували коледжі гігієни та охорони здоров'я. Крім того, разом із коледжами медицини існували коледжі фармації, медсестринства, стоматології, ветеринарної медицини, які більш-менш спиралися на навчальну програму з медичного напряму для створення своїх навчальних планів. Зазначені коледжі запрошували викладати окремі дисципліни професорсько-викладацький склад з медичних коледжів (Weiskotten, 1940).

На думку авторів «Доповіді», така співпраця суттєво впливала на медичну освіту. Медичні коледжі не залишалися осторонь від коледжів фармації, медсестринства, стоматології, ветеринарної медицини та ін. Однак, водночас, вони не могли витрачати занадто багато своїх освітніх ресурсів, виконуючи обов'язки керівного органу у складі певного університету (Weiskotten, 1940).

Що стосується вступу до медичного коледжу, станом на 1934 р. разом із гуманітарними коледжами функціонували коледжі з дворічним терміном навчання (junior colleges), цілі, задачі, методи викладання були схожі на ті, що були в закладах середньої освіти. Однак, таких випускників приймали неохоче, указуючи на неналежну попередню підготовку, 
непристосованість до навчання в медичному коледжі та до університетського життя зокрема (Weiskotten, 1940).

у більшості випадків медичні коледжі після завершення чотирьохрічного курсу навчання присвоювали випускникам ступінь доктора медицини. Однак, деякі вимагали завершити інтернатуру впродовж п'ятого року й присвоювали ступінь бакалавра медицини, у результаті чого випускники були стажистами під загальним керівництвом медичних коледжів (Weiskotten, 1940).

Нові підходи, методи попередження, діагностування та лікування різних хвороб вплинули на концептуальне оновлення навчального плану в медичних коледжах. 3'явилися нові багаточисленні спецкурси, медичні коледжі переглянули вимогу до вступу в бік часткового послаблення. Г. Вайскоттен зазначав, що освітяни-медики «почали прагнути, щоб їхні студенти створили міцне підґрунтя для подальшого кар'єрного зростання в галузі медицині. Визнання широких освітніх цілей є одним із найвагоміших унесків, який колинебудь було зроблено для розвитку професійної освіти» (Weiskotten, 1940).

Важливим також було залучення студентів до опрацювання теоретичного матеріалу в медичних бібліотеках та тісного зв'язку 3 професорсько-викладацьким складом медичних коледжів. Спостерігалася мінімізація запам'ятовування матеріалу з підручників та виконання набору дидактичних вправ (Weiskotten, 1940). Вважаємо, що такі нововведення мали на меті мотивувати студентів до проведення теоретичних i практичних наукових досліджень, розробок і відкриттів.

Під час доклінічного навчання увагу було сфокусовано на людському феномені під час викладання фундаментальних принципів теоретичних медичних наук. Це стимульовано студентів до навчання та успішної професійної діяльності. Також відбулося переосмислення ролі студента в період дворічного клінічного навчання. Студент ставав невід'ємною частиною фахових дисциплін, передбачених навчальним планом медичної практики до отримання ступеня (clinical clerkship).

у 1930-ті університетські медичні коледжі активно створювали спеціальні фонди для організації медичних досліджень, які підтримували меценати, влада штатів, керманичі країни та ін. Тож, як бачимо, проведення досліджень було одним із ключових моментів в американській медичній освіті зазначеного періоду. Перспективних молодих науковців залучали до участі у проєктах під керівництвом професорсько-викладацького складу медичних коледжів з наданням необхідного обладнання, матеріалу, приміщень, окресленням хронологічного періоду виконання досліджень.

Значну кількість годин було відведено на дисципліни «Бактеріологія» та «Імунологія», оскільки «найбільших успіхів з 1890-х до 1930-х. було 
досягнуто в царині бактеріології, нові напрацювання якої легко застосовували в клінічній медицині» (Weiskotten, 1940).

Г. Вайскоттен окреслив такі пріоритетні напрями розвитку інноваційної діяльності університетів, у складі яких були медичні коледжі:

- фінансове та матеріальне заохочення медичних коледжів, особливо під час здійснення прикладних досліджень;

- проведення окремого дослідження щодо розробки спеціальних навчальних програм для нових, супутніх галузей, для таких професій, як лабораторні технології, дієтологія, управління закладами охорони здоров'я, лікувальна фізкультура, ерготерапія тощо;

- спрямування університетом достатньої незалежної фінансової підтримки на створення й підтримку нових навчальних програм, пов'язаних із медициною;

- установлення тісної рівноправної співпраці між медичними коледжами та коледжами фармації, медсестринства, стоматології, ветеринарної медицини тощо, які існують у межах одного університету;

- розроблення змістовних програм післядипломної медичної освіти лише компетентним професорсько-викладацьким складом та керівництвом медичних коледжів;

- створення окремих коледжів післядипломної медичної освіти;

- запровадження усної бесіди (interview) з претендентом на здобуття медичної освіти з метою визначення його психоемоційного стану, ставлення до обраного медичного коледжу, медичної освіти й майбутньої діяльності;

- створення окремих кафедр імунології та бактеріології;

- посилення уваги до курсів з бактеріології та імунології в контексті 4-річного навчального плану для майбутніх лікарів тощо (Weiskotten,1940).

Висновки та перспективи подальших наукових розвідок. Отже, 1930-ті роки були пов'язані зі світовою економічною кризою, яка не оминула й США. Велика депресія негативно позначилася на розвитку американської медичної освіти. Проте, у середині 1930-х рр. Г. Вайскоттен провів дослідженняопитування випускників 1930 р. з метою з'ясування їх кар'єрних успіхів за спеціальністю. Відповіді були неоднозначними, проте всі одноголосно мали наміри допомагати хворим, незважаючи на кризову ситуацію в країні.

у 1934-1939 рр. Г. Вайскоттен також провів масштабне інспектування медичних коледжів США та Канади. Під час цієї перевірки, попри недоліки, було виокремлено й цікаві приклади інноваційної діяльності, зокрема процедура призначення декана медичного коледжу; організація коледжів соціального обслуговування (або соціальної роботи), хіроподії, гігієни та охорони здоров'я, фармації, медсестринства, стоматології, ветеринарної медицини тощо; концептуальне оновлення навчального плану в медичних коледжах у зв'язку з появою нових підходів, методів попередження, діагностування та лікування різних хвороб; залучення студентів до 
опрацювання теоретичного матеріалу в медичних бібліотеках; тісний зв'язок студентів із професорсько-викладацьким складом медичних коледжів; проведення медичних дослідженнях; актуалізація дисциплін «Бактеріологія» та «Імунологія». Крім того, Г. Вайскоттен запропонував загальні пріоритетні напрями інноваційної діяльності американських медичних коледжів.

Перспективами подальших досліджень $€$ висвітлення інноваційної діяльності американських медичних коледжів у воєнний та повоєнний періоди - у 1940-х і 1950-х рр.

\section{ЛІТЕРАТУРА}

Куліченко, А. К. (2020). Інноваційна діяльність у медичній освіті США (10-40рp. XXст.). Педагогічні науки: теорія, історія, інноваційні технології, 7 (81), 3-18 (Kulichenko, A. K. (2020). Innovative activity in US medical education (1910s-1940s). Pedagogical sciences: theory, history, innovative technologies, 7 (81), 3-18).

Мартинов, А. Ю. (2011). Історична компаративістика світових економічних криз (XXпочаток XXI ст.). Український історичний журнал, 5, 131-146 (Martynov, A. Yu. (2011). Historical comparative studies of world economic crises (XX- early XXI ${ }^{\text {st }}$ century). Ukrainian Historical Journal, 5, 131-146).

Academic quality and public accountability in academic medicine. The 75-year history of the LCME (2017). Retrieved from: http://www.lcme.org/wpcontent/uploads/ filebase/articles/October-2017-The-75-Year-History-of-theLCME_COLOR.pdf.

Margo, R. A. (1993). Employment and unemployment in the 1930s. Journal of Economic Perspectives, 7 (2), 41-45.

Rezaee, R., Keshtkar, V. (2013). Basic sciences curriculum in medical education. Journal of Advances in Medical Education \& Professionalism, 1 (1), 28-32.

Steinshouer, B.J. (n.d.). Medical schools in the 1930s. Retrieved from: https:// www.theclassroom.com/medical-schools-1930s-8432730.html

Weiskotten, H. G. (1937). Trends in medical practice. Journal of the Association of American Medical Colleges, 12 (5), 321-355.

Weiskotten, H. G., Schwitalla, A. M., Cutter, W. D., Anderson, H. H. (1940). Medical education in the United States 1934-1939: prepared for the Council on medical education and hospitals of the American medical association. Chicago: American medical association.

Weiskotten, H. G., Wiggins, W. S., Altenderfer, M. E. (1960). Trends in Medical Practice: An Analysis of the Distribution and Characteristics of Medical College Graduates, 19151950. Journal of M edical Education, 35 (12), 1071-1121.

Wilbur, R. L. (1940). Foreword. In Weiskotten, H. G., Schwitalla, A. M., Cutter, W. D., Anderson, H. H. (1940), Medical education in the United States 1934-1939: prepared for the Council on medical education and hospitals of the American medical association (pp. n.a.). Chicago: American medical association.

Wojciech, P. (2009). Basic sciences in medical education: Why? How? When? Where? Medical Teacher, 31 (9), 787-789. DOI: 10.1080/01421590903183803.

\section{PEЗЮME}

Куличенко Алла. Обзор инновационной деятельности американских медицинских колледжей в течение 1934-1939 гг. в работах Г. Вайскоттена.

Статья посвящена анализу работ Г. Вайскоттена, в частности «Тенденции в медицинской практике» (1937), «Медицинское образование в Соединенных Штатах Америки 1934-1939 гг.: подготовлено для Совета по вопросам медицинского 
Педагогічні науки: теорія, історія, інноваційні технології, 2020, № 3-4 (97-98)

образования и больниц Американской медицинской ассоциации» (1940) и «Тенденции в медицинской практике: анализ распределения и характеристик выпускников медицинских колледжей 1915-1950 г2.» (1960), освещающих инновационную деятельность американских медицинских колледжей в 1934-1939 г2. Обнаружено, что Великая депрессия негативно повлияла на развитие медицинского образования США. Однако, определено, что во время экономического кризиса в США Г. Вайскоттен провел а) опрос выпускников 1930 г. и 1935 г. по поводу их карьерных успехов; б) проверку медицинских колледжей США и Канады.

Ключевые слова: американское медицинское образование, Великая депрессия, медицинские колледжи, опросы выпускников, инспектирование, Г.Вайскоттен, «Доклад» Вайскоттена, инновационная деятельность, медицинские исследования.

\section{SUMMARY}

Kulichenko Ala. Review of innovative activity in American medical colleges during 1934-1939 in the works by H. Weiskotten.

The article deals with analysis of the works by $\mathrm{H}$. Weiskotten, in particular, "Trends in M edical Practice" (1937), "M edical Education in the United States 1934-1939: Prepared for the Council on Medical Education and Hospitals of the American Medical Association" (1940) and "Trends in Medical Practice: An Analysis of the Distribution and Characteristics of Medical College Graduates, 1915-1950" (1960). These works highlight the innovative activities of US medical colleges in 1934-1939.

To achieve the objective of the study, the author applies such methods as (i) bibliographic one - to identify scientific and pedagogical sources of different years on the problem; (ii) content analysis, generalization, systematization - to determine certain aspects of the innovative activities of US medical colleges in 1934-1939 and to present them in a comprehensive review.

Note that in the 1930s there was the global economic crisis, which also touched the United States. The Great Depression negatively affected the development of American medical education. However, in the mid-1930s, H. Weiskotten surveyed graduates of 1930 to determine their career success in the field of medicine. The answers were ambiguous, but all graduates unanimously intended to help their patients sick, despite the crisis in the country.

M oreover, during 1934-1939, H. Weiskotten also conducted a large-scale inspection of US medical colleges and those in Canada. Within this inspection, despite the shortcomings, there were interesting examples of innovative activities such as:

- appointing the dean of the medical college;

- organization of colleges of social services (or social work), hygiene and health care, pharmacy, nursing, dentistry, veterinary medicine, etc.;

- conceptual upgrading of the curriculum in medical colleges due to the emergence of new approaches, methods of prevention, diagnosis, and treatment of various diseases;

- close relations between students and the teaching staff of medical colleges;

- conducting medical research;

- actualization of disciplines "Bacteriology" and "Immunology" and so on.

As for the further research, we will cover the innovative activities of US medical colleges in the 1940s and 1950s.

Key words American medical education, Great Depression, medical colleges, surveys, inspection, H. Weiskotten, W eiscotten Report, innovative activity, medical research. 